\title{
PRODUCCIÓN DE LA HORMIGA ESCAMOLERA (Liometopum apiculatum Mayr 1870) Y SU HÁBITAT EN EL ALTIPLANO POTOSINO-ZACATECANO, MÉXICO
}

\author{
PRODUCTION OF THE ESCAMOL ANT (Liometopum apiculatum Mayr 1870) AND ITS HABITAT \\ IN THE POTOSINO-ZACATECANO HIGH PLATEAU, MÉXICO
}

\author{
Benjamín Figueroa-Sandoval ${ }^{1}$, Saúl Ugalde-Lezama ${ }^{2}$, Francisco E. Pineda-Pérez ${ }^{1}$, Gustavo Ramírez- \\ Valverde $^{3}$, Katia A. Figueroa Rodríguez ${ }^{4}$, Luis A. Tarango-Arámbula ${ }^{1 *}$

\begin{abstract}
${ }^{1}$ Colegio de Postgraduados, Campus San Luis Potosí (benjamin@colpos.mx; pineda.francisco@ colpos.mx; ltarango@colpos.mx); ${ }^{2}$ Universidad Autónoma Chapingo (saulu@colpos. $\mathrm{mx}$ ); ${ }^{3}$ Colegio de Postgraduados, Campus Montecillo (gramirez@colpos.mx); ${ }^{4}$ Colegio de
\end{abstract} \\ Postgraduados, Campus Córdoba (fkatia@colpos.mx).
}

\section{RESUMEN}

La hormiga escamolera (L. apiculatum Mayr) es importante económicamente para las comunidades rurales. En cuatro localidades del Altiplano Potosino-Zacatecano, durante la recolecta de escamoles 2010 , se identificaron nidos de la hormiga escamolera, y se determinó su rendimiento, su relación con el hábitat y su tamaño poblacional de sus colonias. En los nidos registrados se evaluaron las variables: condición del nido, calidad del nido, cantidad de hormigas (escasa, regular y abundante), tipo de sustrato de anidación y rendimiento de escamol. La condición de nidos se comparó mediante Índices de Abundancia Relativa, Densidad Relativa. Para determinar la asociación entre la calidad del nido y la cantidad de hormigas se utilizaron las Frecuencias de Observación (FO) y tablas de contingencias independientes de $\chi^{2}$. Para determinar el efecto del sustrato de anidación y el rendimiento del escamol (peso limpio en g) se realizó un ANOVA. Se registraron 77 nidos; la condición del nido que predominó fue la "perturbada" (79 \%), con una densidad relativa promedio de 4.14 nidos $\mathrm{km}^{-1}$. Las FO y el análisis de $\chi^{2}$ identificaron una mayor relación (3.47) entre una cantidad de hormigas escasamala calidad y una cantidad regular de hormigas-muy buena calidad (2.06) del nido $(p=0.001999)$. El ANOVA identificó una relación entre el sustrato de anidación y el rendimiento de escamol $(p=0.0013)$, con un mayor rendimiento en el sustrato de anidación nopal (36\%).

Palabras clave: matorral xerófilo, preferencia, sustratos de anidación.

\footnotetext{
* Autor responsable * Author for correspondence.

Recibido: marzo, 2016. Aprobado: enero, 2018.

Publicado como ARTÍCULO en ASyD 15: 235-245. 2018.
}

\begin{abstract}
The escamol ant ( $L$. apiculatum Mayr) is important economically for rural communities. In four localities of the Potosino-Zacatecano High Plateau, escamol ant nests were identified and their yield was determined, as well as their relation to the habitat and the population size of their colonies during the 2010 harvest of escamoles. In the nests registered the following variables were evaluated: condition of the nest, quality of the nest, amount of ants (scarce, regular and abundant), type of nesting substrate, and escamol yield. The condition of the nests was compared through Indexes of Relative Abundance, Relative Density. To determine the association between quality of the nest and amount of ants, the Observation Frequencies (OF) were used, and the independent contingencies tables of $\chi^{2}$. To determine the effect of the nesting substrate and the escamol yield (clean weight in g), ANOVA was performed. Seventy-seven (77) nests were found; the condition of the nest that predominated was "disturbed" (79\%), with an average relative density of 4.14 nests $\mathrm{km}^{-1}$. The $\mathrm{OF}$ and the $\chi^{2}$ analysis identified a higher relation (3.47) between scarce amount of antsbad quality and regular amount of ants-very good quality (2.06) of the nest $(p=0.001999)$. The ANOVA identified a relationship between the nesting substrate and the escamol yield $(\mathrm{p}=\mathbf{0 . 0 0 1 3})$, with a higher yield in the nopal nesting substrate $(36 \%)$.
\end{abstract}

Key words: xeric scrubland, preference, nesting substrates.

\section{INTRODUCTION}

$\mathrm{I}$ nsects are a very diverse taxonomic group, and more than one million species identified in the world are mentioned (Engel and Grimaldi, 


\section{INTRODUCCIÓN}

$\mathrm{L}$ os insectos son un grupo taxonómico muy diverso se menciona a más de un millón de especies identificadas en el mundo (Engel y Grimaldi, 2004), los cuales varían en formas, tamaños y colores (Lokeshwari y Shantibala, 2010); muchos de ellos son aprovechados para su comercialización como mascotas (Villegas et al., 2005). Sin embargo, estos también se utilizan para el consumo humano (Costa-Neto, 2002). En México se han registrado entre 535 a 549 especies comestibles, las cuales se comercializan en el centro, sur y sureste del país, alcanzando precios altos como platillos gourmet (Ramos-Elorduy y Pino-Moreno, 2005; Costa-Neto y Ramos-Elorduy, 2006; Ramos-Elorduy et al., 2008). Los órdenes con especies de mayor consumo son: Hymenoptera, Orthoptera, Hemiptera y Coleoptera; constituyendo medios de identidad entre diferentes etnias.

En el orden Hymenoptera se incluyen las hormigas en la familia Formicidae, cuya diversidad está determinada por la latitud y altitud (Kusnezov, 1975). La mayor distribución de hormigas ocurre en bosques tropicales y subtropicales de baja altitud, así como en los desiertos cálidos de todo el mundo (Brown et al., 1973).

Una especie importante de la familia Formicidae es Liometopum apiculatum, de la cual las larvas y pupas de sus estados reproductivos (zánganos o princesas), conocidas como escamoles, representan ingresos económicos y alimenticios para las comunidades rurales (Ramos-Elorduy et al., 1984; Dufour, 1987; Ramos-Elorduy, 1991; 2005; 2008; Ramos-Elorduy et al., 2006). En el Altiplano Potosino-Zacatecano esta especie también representa un ingreso económico importante y se recolectan de manera artesanal durante marzo y abril y, en ocasiones, hasta mayo, dependiendo de la temperatura y la precipitación (Cuadrillero-Aguilar, 1980; Ramos-Elorduy et al., 1988; Velasco-Corona et al., 2007). Algunos autores reportan que este recurso se aprovecha en cantidades variables, las cuales oscilan desde $137 \mathrm{~g}$ a $3 \mathrm{~kg}$ por nido (Ramos-Elorduy et al., 1986; Ambrosio-Arzate et al., 2010; Cruz-Labana et al., 2014).

Sin embargo, a pesar de su importancia económi$\mathrm{ca}$, alimenticia y su papel ecológico, $L$. apiculatum ha sido poco estudiada. Los estudios recientes se refieren a la etno-entomológica que tienen las comunidades
2004), which vary in shapes, sizes and colors (Lokeshwari and Shantibala, 2010); many of them are used for their commercialization as pets (Villegas et al., 2005). However, these are also used for human consumption (Costa-Neto, 2002). Between 535 and 549 edible species have been recorded in México, which are commercialized in the center, south and southeast of the country, reaching high prices as gourmet dishes (Ramos-Elorduy and PinoMoreno, 2005; Costa-Neto and Ramos-Elorduy, 2006; Ramos-Elorduy et al., 2008). The orders with species of highest consumption are: Hymenoptera, Orthoptera, Hemiptera and Coleoptera; they also constitute means of identity among different ethnic groups.

The Hymenoptera order includes ants from the Formicidae family, whose diversity is determined by the latitude and altitude (Kusnezov, 1975). The greatest distribution of ants takes place in tropical and subtropical forests of low altitude, as well as in the warm deserts throughout the world (Brown et al., 1973).

An important species of the Formicidae family is Liometopum apiculatum, of which the larvae and pupae from its reproductive phases (drones or princesses), known as escamoles, represent economic and dietary incomes for the rural communities (Ramos-Elorduy et al., 1984; Dufour, 1987; RamosElorduy, 1991; 2005; 2008; Ramos-Elorduy et al., 2006). In the Potosino-Zacatecano High Plateau, this species also represents an important economic income and it is collected in a traditional manner during March and April and, occasionally, until May, depending on the temperature and the precipitation (Cuadrillero-Aguilar, 1980; Ramos-Elorduy et al., 1988; Velasco-Corona et al., 2007). Some authors report that this resource is taken advantage of in variable amounts, which range from $137 \mathrm{~g}$ to $3 \mathrm{~kg}$ per nest (Ramos-Elorduy et al., 1986; AmbrosioArzate et al., 2010; Cruz-Labana et al., 2014).

However, despite its economic and dietary importance, and ecological role, L. apiculatum has been scarcely studied. Recent studies refer to the ethno-entomology that rural communities have with the ant (Dinwiddie et al., 2013), its biology (LaraJuarez et al., 2015), the habitat components that explain the presence of the ant (Cruz-Labana et al., 2014), and even their trophobiotic relation with other insects (Velasco-Corona et al., 2007), and none 
rurales con la hormiga (Dinwiddie et al., 2013), su biología (Lara-Juarez et al., 2015), a los componentes del hábitat que explican la presencia de la hormiga (Cruz-Labana et al., 2014), e incluso hasta su relación trofobiótica con otros insectos (Velasco-Corona et al., 2007), y ninguno explica cómo el tamaño de la colonia y los sustratos de anidación afectan su producción. Por ello, los objetivos del presente trabajo fueron comparar el rendimiento de nidos (perturbados vs conservados) y determinar cómo el tamaño poblacional de la hormiga escamolera y el sustrato de anidación afectan el rendimiento de escamol y calidad del nido de Liometopum apiculatum en cuatro comunidades del Altiplano Potosino-Zacatecano.

\section{Metodología}

El presente trabajo se realizó durante el periodo de recolecta de escamol (marzo y abril) de 2010 en cuatro comunidades de los municipios de Ahualulco, San Luis Potosí y Pinos, Zacatecas (Figura 1). Las explain how the size of the colony and the nesting substrates affect their production. Therefore, the objectives of this study were to compare the yield of nests (disturbed vs conserved) and to determine how the population size of the escamol ant and the nesting substrate affect the yield of escamoles, and the nest quality of Liometopum apiculatum in four communities of the Potosino-Zacatecano High Plateau.

\section{Methodology}

This study was carried out during the period of escamol harvest (March and April) of 2010 in four communities of the municipalities of Ahualulco, San Luis Potosí, and Pinos, Zacatecas (Figure 1). The seats of those municipalities are located on coordinates $22^{\circ} 24^{\prime} \mathrm{N}, 101^{\circ} 10^{\prime} \mathrm{W}$ and $22^{\circ} 16^{\prime} \mathrm{N}, 101^{\circ} 34^{\prime} \mathrm{W}$. Ahualulco, San Luis Potosí, has an average altitude of $1850 \mathrm{~m}$ and Pinos, Zacatecas, of $2419 \mathrm{~m}$. According to García (1998), the climate for both municipalities

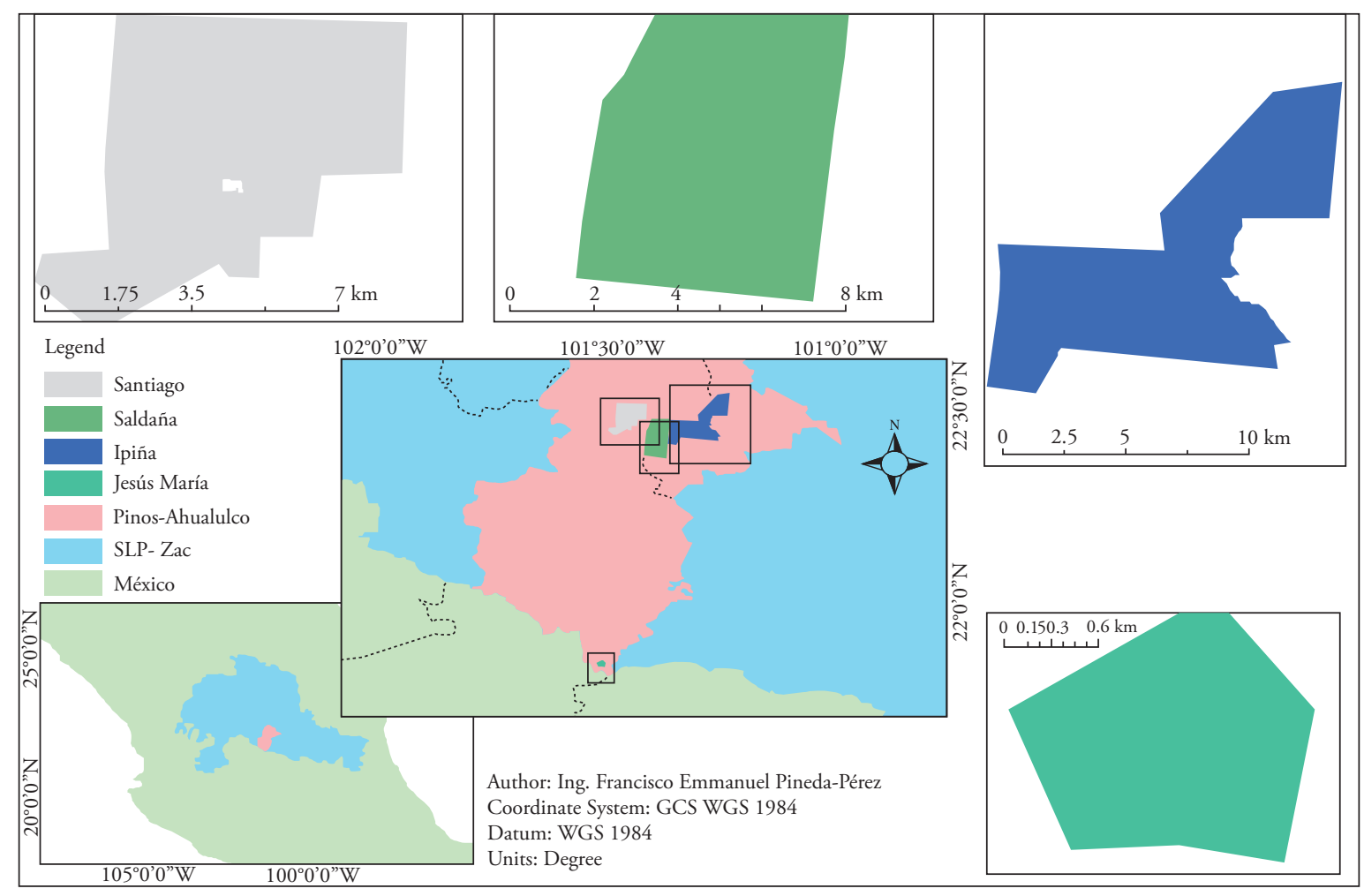

Figura 1. Comunidades del Altiplano Potosino-Zacatecano estudiadas: Ipiña, Ahualulco, San Luis Potosí; Jesús María, Saldaña y Santiago, Pinos, Zacatecas.

Figure 1. Communities of the Potosino-Zacatecano High Plateau: Ipińa, Ahualulco, San Luis Potosí; Jesús María, Saldaña and Santiago, Pinos, Zacatecas. 
cabeceras de dichos municipios se ubican en las coordenadas $22^{\circ} 24^{\prime} \mathrm{N}, 101^{\circ} 10^{\prime} \mathrm{W}$ y $22^{\circ} 16^{\prime} \mathrm{N}, 101^{\circ}$ 34 ' W. Ahualulco, San Luis Potosí tiene una altitud promedio de $1850 \mathrm{~m}$ y Pinos, Zacatecas de $2419 \mathrm{~m}$. De acuerdo con García (1998), el clima para ambos municipios corresponde al semi-árido templado (BS$\left.{ }_{1} \mathrm{kw}\right)$ y la vegetación; en su mayoría, corresponde a matorral micrófilo, crassicaule y rosetófilo, con algunas zonas de zacatal (Rzedowsky, 1978; Rzedowsky y Huerta, 1994).

En las cuatro comunidades seleccionadas para la recolecta de escamol de L. apiculatum y para localizar colonias y nidos de la hormiga escamolera se llevó a cabo un muestreo sistemático. Este consistió en realizar recorridos por las comunidades seleccionadas en horarios de 6:00 a 16:00 horas con el apoyo de un guía recolector y tomando en cuenta la técnica tradicional utilizada por los recolectores de escamoles de la zona, la cual consistió en: a) buscar los caminos de forrajeo de la hormiga; b) ubicar el nido en la intersección de los caminos; y c) excavar y extraer el escamol. Una vez extraído el escamol, este se cribó, se lavó y se pesó.

Para cada nido se registraron las siguientes variables: condición del nido (perturbado vs conservado) determinada con base en su estado de conservación; calidad del nido (muy buena, buena, regular, mala y muy mala, característica determinada con base en el aprovechamiento anterior del nido); cantidad de hormigas (escasa, regular y abundante), tipo de sustrato de anidación y rendimiento de escamol (g). La cantidad de hormigas de la colonia se cuantificó de forma visual. Asimismo, a los nidos encontrados se les registraron sus coordenadas UTM con un Sistema de Posicionamiento Global. Con esta información se crearon los puntos de referencia de cada nido y se elaboró el mapa de su localización con un Sistema de Información Geográfica (SIG) en el software ArcGis 10.1 (ESRI, 2012).

Para determinar la abundancia de nidos se utilizó el Índice de Abundancias Relativas (IAR) (Jenks et al., 2011) con modificaciones para el presente estudio: $I A R=(N$ cond $/ N T) \times 100$; donde $N$ cond: número nidos con cierto tipo de condición, $N T$ : número total de nidos. Para obtener el número de nidos con diferente condición por comunidad se determinó la Densidad Relativa $(D P)$ de nidos perturbados y conservados de acuerdo con la ecuación de Hayne por franjas (Martella et al., 2012) modificada para corresponds to semi-arid temperate $\left(\mathrm{BS}_{1} \mathrm{kw}\right)$ and the vegetation, in majority, corresponds to microphyll, crassicaule and rosetophyll, with some grassland zones (Rzedowsky, 1978; Rzedowsky and Huerta, 1994).

In the four communities selected for the escamol collection of $L$. apiculatum and to locate colonies and nests of the escamol ant, a systematic sample was carried out. This consisted in performing visits to the communities selected in a schedule of 6:00 to $16: 00$ hours with the support of a collector guide, and taking into account the traditional technique used by escamol collectors in the zone, which consisted in: a) searching for the foraging paths of the ant; b) locating the nest in the path intersection; and c) excavating and extracting the escamol. Once the escamol was extracted, it was sieved, washed and weighed.

For each nest, the following variables were recorded: nest condition (disturbed vs conserved) which was determined based on its state of conservation; nest quality (very good, good, regular, bad and very bad, characteristic determined based on the prior exploitation of the nest); amount of ants (scarce, regular and abundant), type of nesting substrate and escamol yield (g). The amount of ants from the colony was quantified visually. Likewise, for the nests found their UTM coordinates were recorded with a Global Positioning System. With this information the reference points of each nest were created, and the map of their localization was elaborated with a Geographic Information System (GIS) in the ArcGis 10.1 software (ESRI, 2012).

In order to determine the abundance of nests, the Relative Abundance Index (RAI) was used (Jenks et al., 2011), with modifications for this study: $R A I=(N$ cond $/ N T) \times 100$; where $N$ cond: number of nests with a certain type of condition, NT: total number of nests. To obtain the number of nests with different condition by community, the Relative Density (DP, for its initials in Spanish) of disturbed and conserved nests was defined according to the Hayne equation by bands (Martella et al., 2012) modified for this study. The equation that describes it is: $D P=(1 / F) \times\left[\Sigma\left(z_{i} / D_{i}\right)\right]$; where $F$ : number of localities sampled, $z_{i}$ : number of nests with certain condition per locality, $D_{\text {: }}$ d distance of visit per zone. The software used to calculate this index was Excel 2013 (Microsoft, 2013). 
el presente estudio. La ecuación que la describe es: $D P=(1 / F) \times\left[\Sigma\left(z_{\mathrm{j}} / D_{\mathrm{j}}\right)\right]$; donde $F$ : número de localidades muestreadas, $z$ : número de nidos con cierta condición por localidad, $D_{j}$ : distancia de recorrido por zona. El programa utilizado para calcular este índice fue Excel 2013 (Microsoft, 2013).

Para determinar la frecuencia de nidos con cierta calidad se realizó un análisis tendencial-gráfico de Frecuencia de Observación (FO) (Curts, 1993) modificado, como a continuación se detalla: $\mathrm{FO}=($ No. de nidos con muchas hormigas con cierta calidad / No. total de nidos con muchas hormigas) $\times 100$. Para determinar la asociación en función de la cantidad de hormigas y el rendimiento del nido, en términos de su calidad, se elaboró una tabla de contingencia de $\chi^{2}$, utilizando como nivel de asociación los valores estandarizados. Se obtuvo el estadístico Chi-cuadrado de Pearson (Agresti, 2003) y para ajustar el tamaño de muestreo se utilizó el programa R-Commander ( $\mathrm{R}, 2014)$ donde se simuló el "test" de $\chi^{2}$ en 2000 repeticiones.

La información de rendimiento de escamol se homogenizó para poderla utilizar de forma cualitativa, donde el peso en limpio del escamol se categorizó en producción escasa y producción abundante. Para ello, el peso del escamol limpio se clasificó como de bajo rendimiento cuando sus valores fueron $\leq$ mediana y de alto rendimiento cuando sus valores fueron $>$ mediana. Las FO se utilizaron para determinar las preferencias por sustratos de anidación de L. apiculatum.

Para determinar diferencias entre sustratos de anidación, rendimiento y sustrato de anidación se utilizó un Análisis de Varianza (ANOVA) (Fisher, 1993; Molinero, 2003). Para este análisis se agruparon los sustratos en tres categorías: Nopal como "Sustrato 1", Maguey como "Sustrato 2", y el garabatillo (Mimosa biuncifera), mezquite (Prosopis laevigata), huizache (Acacia farnesiana), palma (Yucca spp.), garambullo (Myrtillocactus geometrizans), crucilla (Randia echinocarpa) y biznaga (Echinocactus spp.) incluyeron el "Sustrato 3". La variable sustrato se tomó como todo aquel ítem en el cual la hormiga pudiese ubicar sus nidos. Para evitar un sesgo por el tamaño de muestra, igualmente se realizó una transformación de la variable de respuesta "Rendimiento en gramos (escamol limpio)" a Ln (Logaritmo Natural); para ello se utilizó el programa InfoStat v.2013 (Di Rienzo et al., 2013).
To determine the frequency of nests with certain quality a trend-graphic analysis of Observation Frequency (OF) was carried out (Curts, 1993), modified as detailed next: $\mathrm{OF}=($ No. of nests with many ants with certain quality / Total no. of nests with many ants $) \times 100$. To determine the association in function of the amount of ants and the nest yield, a $\chi^{2}$ contingency table was elaborated in terms of its quality, using the standardized values as level of association. Pearson's square-chi statistic was obtained (Agresti, 2003) and the R-Commander software (R, 2014) was used to adjust the sample size, where the $\chi^{2}$ "test" was simulated in 2000 repetitions.

The information of escamolyield was homogenized to be able to use it in a qualitative way, where the clean weight of the escamol was categorized as scarce production and abundant production. For this, the weight of the clean escamol was classified as of low yield when its values were $\leq$ median and of high yield when its values were $>$ median. The OFs were used to determine the preferences for nesting substrates of L. apiculatum.

To determine differences between nesting substrates, yield and nesting substrate, a analysis of variance (ANOVA) was used (Fisher, 1993; Molinero, 2003). For this analysis, the substrates were grouped into three categories: Nopal as "Substrate 1", Maguey as "Substrate 2", and garabatillo (Mimosa biuncifera), smooth mesquite (Prosopis laevigata), sweet acacia (Acacia farnesiana), yucca (Yucca spp.), garambullo (Myrtillocactus geometrizans), crucilla (Randia echinocarpa) and biznaga (Echinocactus spp.) were included in "Substrate 3". The substrate variable was taken as any item in which the ant could place its nests. To avoid a bias from the size of the sample, a transformation of the response variable "Yield in grams (clean escamol)" into Ln (Natural Logarithm) was performed; for this purpose, the InfoStat v.2013 software was used (Di Rienzo et al., 2013).

\section{Results AND Discussion}

In this study, 77 nests were found and evaluated in four localities of the Potosino-Zacatecano High Plateau (Figure 2). Of these, 16 presented a conserved condition and 61 were disturbed; the density of conserved and disturbed was 2.25 and 4.14 nests $\mathrm{km}^{-1}$, respectively. The production of those conserved was 543.1 $\pm-564.1 \mathrm{~g}$ and of those 


\section{Resultados y Discusión}

En este estudio se encontraron y evaluaron 77 nidos en cuatro localidades del Altiplano PotosinoZacatecano (Figura 2). De estos, 16 presentaron una condición conservada y en 61 estuvo perturbada; la densidad de conservados y perturbados fue de 2.25 y 4.14 nidos $\mathrm{km}^{-1}$, respectivamente. La producción de los conservados fue de $543.1 \pm-564.1 \mathrm{~g}$ y de los perturbados, de 169.2 $\pm-301.0 \mathrm{~g}$ (Cuadro 1). La densidad de nidos conservados y perturbados fue de 2.25 y 4.14 nidos $\mathrm{km}^{-1}$, respectivamente. De las cuatro localidades, Ipiña, Ahualulco, San Luis Potosí produjo menos escamol y el sustrato de anidación en el que la hormiga escamolera produjo más escamol fue el "Nopal". Una producción baja de escamol y una densidad alta de nidos perturbados son indicadores del uso intensivo de este recurso natural; por ello, se ha propuesto un mejor control, demandando legislar sobre el aprovechamiento de las larvas de la hormiga disturbed, 169.2 $\pm-301.0 \mathrm{~g}$ (Table 1 ). The density of conserved and disturbed nests was 2.25 and 4.14 nests $\mathrm{km}^{-1}$, respectively. Of the four localities, Ipiña, Ahualulco, San Luis Potosí, produced less escamol and the nesting substrate on which the escamol ant produced more escamol was "Nopal". A low production of escamol and a high density of disturbed nests are indicators of the intensive use of this natural resource; therefore, a better control has been proposed, demanding legislation about the exploitation of the escamol ant larvae. There is insistence in the transference of knowledge and a better organization of the collectors for production (Ramos-Elorduy et al., 2006; Ambrosio-Arzate et al., 2010, Tarango-Arámbula, 2012).

According to the t-Student analysis, statistically significant differences were found $(p<0.001)$ between the production of escamoles from conserved vs disturbed nests (Table 2).

The OFs identified a better quality of the nest when there was a regular amount of ants $(63 \%)$

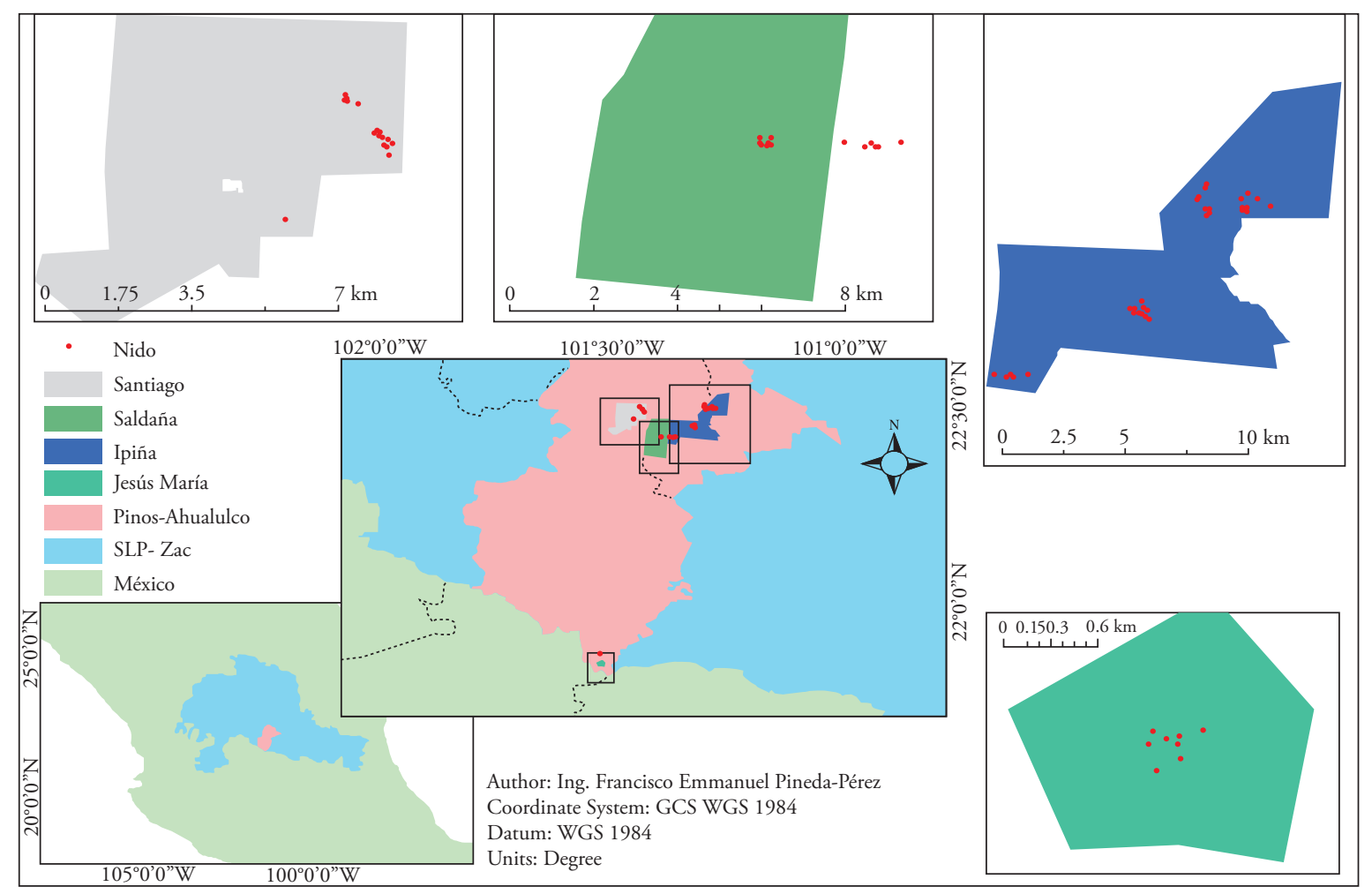

Figura 2. Nidos de la hormiga escamolera en cuatro localidades del Altiplano Potosino-Zacatecano; Ipińa (Ahualulco, San Luis Potosí); Jesús María, Saldańa y Santiago (Pinos, Zacatecas).

Figure 2. Escamol ant nests in four localities of the Potosino-Zacatecano High Plateau; Ipińa (Ahualulco, San Luis Potosí); Jesús María, Saldańa and Santiago (Pinos, Zacatecas). 
Cuadro 1. Rendimiento de escamol por localidad, sustrato de anidación y condición del nido de Liometopum apiculatum Mayr.

Table 1. Escamol yield per locality, nesting substrate and nest condition of Liometopum apiculatum Mayr.

\begin{tabular}{|c|c|c|}
\hline $\begin{array}{c}\text { Localidad/Sustrato/ } \\
\text { Condición }\end{array}$ & $\begin{array}{c}\text { Promedio } \\
(\mathrm{g})\end{array}$ & $\begin{array}{c}\text { Desviación } \\
\text { estándar }\end{array}$ \\
\hline Ipiña & 169.2 & 308.3 \\
\hline Nopal (Opuntia spp.) & 382.0 & 485.9 \\
\hline Conservado & 1500.0 & 0.0 \\
\hline Perturbado & 257.8 & 328.7 \\
\hline Maguey (Agave spp.) & 104.4 & 188.3 \\
\hline Conservado & 410.0 & 400.0 \\
\hline Perturbado & 72.2 & 107.1 \\
\hline Otros & 99.4 & 162.8 \\
\hline Conservado & 505.0 & 0.0 \\
\hline Perturbado & 58.8 & 105.1 \\
\hline Jesús María & 349.4 & 276.7 \\
\hline Nopal & 537.5 & 314.1 \\
\hline Conservado & 537.5 & 314.1 \\
\hline Maguey & 199.0 & 89.1 \\
\hline Conservado & 199.0 & 89.1 \\
\hline Saldaña & 345.7 & 203.8 \\
\hline Nopal & 345.7 & 203.8 \\
\hline Conservado & 0.0 & 0.0 \\
\hline Perturbado & 403.3 & 158.7 \\
\hline Santiago & 333.0 & 585.7 \\
\hline Nopal & 430.6 & 631.5 \\
\hline Conservado & 1360.0 & 650.0 \\
\hline Perturbado & 120.8 & 83.5 \\
\hline Maguey & 84.7 & 77.7 \\
\hline Perturbado & 84.7 & 77.7 \\
\hline Otros & 1060.0 & 890.0 \\
\hline Perturbado & 1060.0 & 890.0 \\
\hline Total general & 246.7 & 398.1 \\
\hline Conservado & 543.1 & 564.1 \\
\hline Perturbado & 169.2 & 301.0 \\
\hline
\end{tabular}

escamolera. Se insiste en la transferencia del conocimiento y una mejor organización de los recolectores para la producción (Ramos-Elorduy et al., 2006; Ambrosio-Arzate et al., 2010; Tarango-Arámbula, 2012).

De acuerdo con el análisis t-Student se registraron diferencias estadísticamente significativas $(\mathrm{p}<0.001)$ entre la producción de escamoles de nidos conservados vs perturbados (Cuadro 2).

Las FO identificaron una mejor calidad del nido cuando hubo una cantidad regular de hormigas (63 \%) y una mala calidad de éste con una cantidad escasa (100\%). Esto se confirmó a través del análisis de las desviaciones de lo esperado bajo independencias estandarizadas de Chi-cuadrada, el cual registró and a bad quality of the nest with scarce amount of ants $(100 \%)$. This was confirmed through the analysis of the deviations from what was expected under standardized independencies of Chi-square, which recorded a strong association between a very bad quality of the nest with a scarce amount of ants (3.47) and a very good quality of the nest with a regular amount of ants (2.06) $(\mathrm{p}=0.001999)$ (Table 3).

The amount of $L$. apiculatum ants can reach 250000 individuals per nest (Hoey-Chamberlain et al., 2013); however, an excessive increase of the population can cause a decrease in the nest quality, decreasing its productivity. This study only evaluated basic aspects such as the quality of the nest and its yield on the relationship of the number of ants and nesting substrates with the nest quality. However, the higher number of disturbed nests found in this study, which are associated with a low yield of escamoles (Table 1), suggests the need to undertake long-term studies that help to explain the factors that best define a higher production of escamoles.

The disturbance of ecosystems intervenes in the diversity of the habitat, particularly in the mirmecofauna of the site; for example, in very disturbed ecosystems the diversity of ants decreases and the species of generalist ants become established and dominate the populations of other species (Alfonso et al., 2010; Ruiz-Cancino et al., 2010; Tizón et al., 2010; Chanatásig-Vaca et al., 2011; Martínez et al., 2015). Cruz-Labana et al. (2014) performed a study of the escamol ant in a similar type of vegetation to where this research was developed, finding that the habitats that the escamol ant prefers are the ones moderately disturbed. Therefore, it is important to manage the habitat of L. apiculatum and their nests to avoid extreme variations in their population size that place the colony at risk.

The ANOVA found significant differences between the yield and the nesting substrate $\left(F_{(2,2)}=\right.$ $7.55 \mathrm{p}=0.0013)$. The "nopal" (36\%) nesting substrate produced a high yield, while the "maguey" substrate (54\%) indicated a low production; however, the substrate "others" participated more equitably in all the categories of yield (Table 1). However, it was observed that $L$. apiculatum produced more escamol on the "nopal" substrate and that this species could select nopal preferably to nest, as well as others do to select their foraging substrate (Stradling, 1978; 
una asociación fuerte entre una muy mala calidad del nido con una cantidad escasa de hormigas (3.47) y una calidad del nido muy buena con una cantidad regular de hormigas (2.06) $(\mathrm{p}=0.001999)$ (Cuadro 3).

La cantidad de hormigas de L. apiculatum puede alcanzar los 250000 individuos por nido (HoeyChamberlain et al., 2013); sin embargo, un incremento excesivo de la población puede causar un decremento en la calidad del nido, bajando su productividad. La presente investigación solo evaluó aspectos básicos como la calidad del nido y su rendimiento sobre la relación del número de hormigas y sustratos de anidación con la calidad del nido. Sin embargo, el número mayor de nidos perturbados registrados en este estudio, los cuales se asocian con un rendimiento bajo de escamoles (Cuadro 1), sugiere la necesidad de emprender estudios a largo plazo que ayuden a explicar los factores que mejor determinan una mayor producción de escamoles.

La perturbación de los ecosistemas interviene en la diversidad del hábitat, sobre todo en la mirmecofauna del sitio; por ejemplo, en los ecosistemas muy perturbados la diversidad en hormigas decrece y las especies de hormigas generalistas se establecen y dominan a las poblaciones de otras especies (Alfonso et al., 2010; Ruiz-Cancino et al., 2010; Tizón et al., 2010; Chanatásig-Vaca et al., 2011; Martínez et al., 2015). Cruz-Labana et al. (2014) realizaron un estudio de la hormiga escamolera en un tipo de vegetación similar a donde se desarrolló esta investigación, determinando que los hábitats que la hormiga escamolera prefiere son los moderadamente perturbados. Por ello, es importante manejar el hábitat de L. apiculatum y de sus nidos para evitar variaciones extremas en su tamaño poblacional que pongan en peligro a la colonia.

El ANOVA registró diferencias significativas entre el rendimiento y el sustrato de anidación $\left(F_{(2,2)}=\right.$ $7.55 \mathrm{p}=0.0013)$. El sustrato de anidación "nopal" (36\%) produjo un rendimiento alto, mientras que el de "maguey" (54\%) indicó una producción baja; sin embargo, el sustrato "otros" participó más equitativamente en todas las categorías de rendimiento (Cuadro 1). Sin embargo, se observó que L. apiculatum produjo más escamol en el sustrato "nopal" y que esta especie pudiera seleccionar al nopal preferentemente para anidar, así como lo hacen otras para seleccionar sus sustratos forrajeros (Stradling, 1978; Rojas-Fernández, 2001; Cortes-Pérez et al., 2003; Pirk et al., 2004) y de anidación en sus diferentes hábitats.
Cuadro 2. Resultados del análisis t-Student para la producción de escamoles en nidos conservados $v s$ perturbados por localidad y general.

Table 2. Results from the t-Student analysis for the production of escamoles in conserved $v s$ disturbed nests per locality and in general.

\begin{tabular}{lll}
\hline Localidad $^{*}$ & Valor $t$ & \multicolumn{1}{c}{ Prob. } \\
\hline Ipiña & -8.8292 & $4.96 \mathrm{E}-11$ \\
Saldaña & -2.5 & 0.0465 \\
Santiago & -5.4571 & $3.49 \mathrm{E}-05$ \\
\hline Todos & -6.2786 & $1.94 \mathrm{E}-08$ \\
\hline
\end{tabular}

*En la localidad Jesús María no se registraron nidos "perturbados" por lo que no se incluyó en el análisis. * No "disturbed" nests were found in the locality of Jesús María, so it was not included in the analysis.

Rojas-Fernández, 2001; Cortes-Pérez et al., 2003; Pirk et al., 2004), and nest in their different habitats.

It is quite likely that Liometopum apiculatum presents a similar pattern when associating to habitats with rosetophyll shrubs in arid and semiarid zones of México (Esparza-Frausto et al., 2008; Cruz-Labana et al., 2014); however, they also seem to have plasticity on the use of different ecosystems as other authors report (Ramos-Elorduy et al., 1986; Velasco-Corona et al. 2007; Hoey-Chamberlain et al., 2013).

The escamol ant seems to present a pattern of higher productivity when associating to microphyll, rosetophyll and crassicaule shrubs, and, specifically, to larger vegetative structures such as nopal (Opuntia spp.), maguey (Agave spp.) and yucca (Yucca spp.)

Cuadro 3. Relación entre calidad del nido y cantidad de hormigas a través de las desviaciones esperadas bajo independencias estandarizadas.

Table 3. Relation between nest quality and amount of ants through the deviations expected under standardized independencies.

\begin{tabular}{lccc}
\hline \multirow{2}{*}{ Calidad del nido } & \multicolumn{3}{c}{ Cantidad de hormigas } \\
\cline { 2 - 4 } & Abundante & Regular & Escasa \\
\hline Muy mala & -1.55 & 1.11 & 3.47 \\
Mala & 0.87 & -1.66 & -0.74 \\
Regular & 0.54 & 0.47 & -1.10 \\
Buena & 0.50 & -0.76 & -0.65 \\
Muy Buena & -0.43 & 2.06 & -1.06 \\
\hline Total & -0.07 & 1.22 & -0.08 \\
\hline
\end{tabular}


Es muy probable que Liometopum apiculatum presente un patrón similar al asociarse a hábitats con matorrales rosetófilos en zonas áridas y semiáridas de México (Esparza-Frausto et al., 2008; Cruz-Labana et al., 2014); sin embargo, también parece tener una plasticidad sobre el uso de diferentes ecosistemas como lo reportan otros autores (Ramos-Elorduy et al., 1986; Velasco-Corona et al. 2007; Hoey-Chamberlain et al., 2013).

La hormiga escamolera parece presentar un patrón de mayor productividad al asociarse a matorrales micrófilos, rosetófilos y crasicaule y, en específico, a estructuras vegetativas mayores como nopales (Opuntia spp.), magueyes (Agave spp.) y palmas (Yucca spp.) que le ofrecen sitios potenciales de anidación, de forrajeo, protección termal y la posibilidad de tener relaciones interespecíficas con otros insectos de los cuales se alimenta (Novoa et al. 2005; Velasco-Corona et al. 2007; Miranda et al. 2012). Lo anterior puede explicarse con el estudio de Novoa et al. (2005), quienes encontraron que Camponotus spp. prefiere estructuras vegetales como las cactáceas atraídas por sus azúcares y botones florales.

Si bien los sustratos de anidación tienen una influencia en la producción de escamol, también la longevidad del nido, entre otros factores, es importante (JuárezSandoval et al., 2010). Este estudio aporta información básica sobre algunos factores involucrados en la producción de escamoles; sin embargo, para proporcionar un mejor manejo a las colonias de la hormiga escamolera y sus hábitats es necesario entender las variables que mejor explican su presencia; asimismo, se requiere conocer el tamaño real del nido y de las colonias, así como sus patrones y distancias de forrajeo (González-Espinosa, 1984; Gómez y Espadaler, 1996; Jofré y Medina, 2012).

\section{Conclusiones}

Se registraron y evaluaron 77 nidos en cuatro localidades del Altiplano Potosino-Zacatecano. De ellos, 61 presentaron una condición perturbada y 16 una condición conservada.

La densidad de nidos conservados y perturbados fue de 2.25 y 4.14 nidos $\mathrm{km}^{-1}$, respectivamente.

Los nidos con una condición conservada produjeron más escamoles $(543.1 \mathrm{~g})$ que los que la tuvieron perturbada (169.2 g).

Se registró una asociación fuerte entre una muy mala calidad del nido con una cantidad escasa de hormigas (3.47) y una muy buena con una cantidad regular. that offer potential nesting sites, for foraging, thermal protection, and the possibility of having inter-specific relations with other insects on which it feeds (Novoa et al. 2005; Velasco-Corona et al. 2007; Miranda et al. 2012). This can be explained with the study by Novoa et al. (2005), who found that Camponotus spp. prefers plant structures such as cactuses, attracted by their sugars and flower buttons.

Although the nesting substrates have an influence on the production of escamol, the longevity of the nest is also important, among other factors (JuárezSandoval et al., 2010). This study contributes basic information about some factors involved in the production of escamoles; however, to provide a better management of the escamol ant colonies and their habitats, it is necessary to understand the variables that best explain their presence; likewise, the real size of the nest and the colonies should be understood, as well as their patterns and foraging distances (González-Espinosa, 1984; Gómez and Espadaler, 1996; Jofré and Medina, 2012).

\section{ConClusions}

Seventy-seven (77) nests were found and evaluated in four localities of the Potosino-Zacatecano High Plateau. Of these, 61 presented a disturbed condition and 16 a conserved condition.

The density of conserved and disturbed nests was 2.25 and 4.14 nests $\mathrm{km}^{-1}$, respectively.

The nests with a conserved condition produced more escamoles $(543.1 \mathrm{~g})$ than those that were in a disturbed condition (169.2 g).

A strong association was found between a very bad quality of the nest with scarce quality of ants (3.47) and between a very good one with regular amount.

There is greater relation in the yield of trabeculae in function of a very good quality of the nest, associated when there is a "regular" amount of ants in it; contrary case, a bad quality is associated to a "scarce" amount of ants.

Of the four localities, Ipiña, Ahualulco, San Luis Potosí produced less escamol and the nesting substrate on which the escamol ant produced more was "Nopal".

- End of the English version - 
Existe mayor relación en el rendimiento de las trabéculas en función de una muy buena calidad del nido, asociado cuando en este hay una cantidad "regular" de hormigas; caso contrario, una mala calidad está asociada a una cantidad "escasa de hormigas".

De las cuatro localidades, Ipiña, Ahualulco, San Luis Potosí produjo menos escamol y el sustrato de anidación en el que la hormiga escamolera produjo más fue el "Nopal".

\section{Literatura Citada}

Agresti, Alan. 2003. Categorical Data Analysis Second Edition. New Jersey, USA, John Wiley and Sons, Inc. Hoboken. 732 p. Alfonso Simonetti, Janet, Yaril Matienzo Brito, y Luis L. VázquezMoreno. 2010. Fauna de hormigas (Hymenoptera: Formicidae) asociadas a un sistema de producción agrícola urbano. Fitosanidad. Vol. 14, núm. 3. pp: 153-158.

Ambrosio-Arzate, Gabriela Alejandra, Rubén Nieto-Hernández, Sotero Aguilar-Mendel, y Angélica Espinoza-Ortega. 2010. Los insectos comestibles: un recurso para el desarrollo local en el centro de México. Spatial Dynamics in Agri-Food systems: Implications for sustainability and consumer welfare. Parma, Italy.

Brown, Jessi, Steve Vargo, Edward Connor, and Michael Nuckols. 1973. Causes of vertical stratification in the density of Cameraria hamadryadella. Ecological Entomology. Vol. 22, Num. 1. pp: 16-25.

Chanatásig-Vaca, Cristina Isabel, Esperanza Huerta-Lwanga, Patricia Rojas-Fernández, Alejandro Ponce-Mendoza, Jorge Mendoza-Vega, Alejandro Morón-Ríos, Hans Van Der Wal, y Benito Bernardo Dzib-Castillo. 2011. Efecto del uso del suelo en las hormigas (Formicidae: Hymenoptera) de Tikinmul, Campeche, México. Acta Zoológica Mexicana. Vol. 27, Núm. 2. pp: 441-461.

Cortes-Pérez, Francisco, León-Sicard, y Tomás Enrique. 2003. Modelo conceptual del papel ecológico de la hormiga arriera (Atta leavigata) en los ecosistemas de sabana estacional (Vichada, Colombia). Caldasia. Vol. 25, Núm 2. pp: 403-417.

Costa-Neto, Eraldo M. 2002. Manual de etnoentomología. Zaragoza, España. Sociedad Entomológica Aragonesa. 256 p.

Costa-Neto, Eraldo M., y Julieta Ramos-Elorduy. 2006. Los insectos comestibles de Brasil: etnicidad, diversidad e importancia en la alimentación. Bol. de la Soc. Ent. Aragonesa. Vol. 38, pp: 423-442.

Cuadrillero Aguilar, José Ignacio. 1980. Consideraciones biológicas y económicas acerca de los Escamoles. Tesis Facultad de Ciencias, UNAM, Ciudad de México.

Cruz-Labana, José Domingo, Luis Antonio Tarango-Arámbula, José Luis Alcantara-Carbajales, José Pimentel-López, Saúl UgaldeLezama, Gustavo Ramirez-Valverde, y S. J. Méndez-Gallegos. 2014. Uso del hábitat por la hormiga escamolera (Liometopum apiculatum Mayr) en el Centro de México. Agrociencia. Vol. 48, Núm. 6. pp: 569-582.

Curts, Jaime. 1993. Análisis exploratorio de datos. In: P. M. A. Salas, y C. O. Trejo. 1993. Las aves de la Sierra Purépecha del Estado de Michoacán. Coyoacán, México, SARH División Forestal, p. 14 (Boletín Informativo \#79).

Di Rienzo J. A., F. Casanoves, M. G. Balzarini, L. Gonzalez, M.
Tablada, y C. W. Robledo. 2013. InfoStat versión 2013. Grupo InfoStat, FCA, Universidad Nacional de Córdoba, Argentina. URL http://www.infostat.com.ar

Dinwiddie, M. L., R. W. Jones, P. Roitman-Genoud, L. A. TarangoArámbula, y G. X. Malda-Barrera. 2013. Estudio entoentomológico de la hormiga escamolera (Liometopum apiculatum) en dos localidades en el estado de Querétaro. Agroproductividad. Vol. 6, Núm. 5. pp: 27-34.

Dufour, Darma. 1987. Insects as food. A case study from the northwest Amazon. Amer. Anthropol. Vol. 89, Num. 2. pp: 383397.

Engel, Michael S., and David A. Grimaldi. 2004. New light shed on the oldest insect. Nature. Vol. 427, Num. 6975. pp: 627-630.

Esparza-Frausto, Gastón, Francisco J. Macías-Rodríguez, Martín Martínez-Salvador, Marco A. Jiménez-Guevara, y Santiago de J. Méndez-Gallegos. 2008. Insectos comestibles asociados a las Magueyeras en el Ejido, Tolosa, Pinos, Zacatecas, México. Agrociencia. Vol. 42, Núm. 2. pp: 243-252.

ESRI. 2012. ArcGis 10.1.

Fisher, Ronald Aylmer. 1993. Statistical methods experimental design and scientific inference. New York, U.S.A. Oxford Science Publications. New Science Publications. 182 p.

García, Enriqueta. 1998. Climas, escala 1:1 000 000. CONABIO.

Gómez, Crisanto, y Xavier Espadaler. 1996. Distancias de forrajeo, áreas de forrajeo y distribución espacial de nidos de Aphaenogaster senilis Mayr (Hym:Formicidae). Miscelánia Zoológica. Vol. 19, Núm. 2. pp: 19-25.

González-Espinosa, Mario. 1984. Patrones de comportamiento de forrajeo de hormigas recolectoras Pogonomyrmex spp. en ambientes fluctuantes (Hymenoptera: Formicidae). Folia Entomológica Mexicana, Vol. 61, Núm. pp: 147-158.

Hoey-Chamberlain, Rochelle, Michael K. Rust, and John H. Klotz. 2013. A review of the biology, ecology and behavior of velvety tree ants of North America. Sociobiology. Vol. 60, Núm. 1. pp: $1-10$.

Jenks, Keith E., Prawatsart Chanteap, Kanda Damrongchainarog, Peter Cutter, Passanan Cutter, Tim Redford, Antony J. Lynam, JoGayle Howard, and Peter Leingruber. 2011. Using relative abundance indices from camera-trapping to test wildlife conservation hypotheses -an example from Khao Yai National Park, Thailand. Tropical Conservation Science, Vol. 4, Num. 2. pp: 113-131.

Jofré, Laura, y Ana I. Medina. 2012. Patrones de actividad forrajera y tamaño de nido de Acromyrmex lobicornis (Hymenoptera: Formicidae) en una zona urbana de San Luis, Argentina. Rev. Sociedad Entomológica Argentina. Vol. 71, Núm. 1-2. pp: $37-$ 44.

Juárez-Sandoval, José de Jesús, Virginia Eustolia Melo-Ruiz, Demetrio Pérez-Santiago, y Concepción Calvo-Carrillo. 2010. Contenido de proteínas y aminoácidos en Escamoles (Liometopum apiculatum M.) capturados en el estado de Hidalgo. Congreso Internacional QFB No.10. San Nicolás de los Garza, México. In: Revista Salud Pública y Nutrición Edición Especial No. 10.

Kusnezov, N. 1975. Numbers of species of ants in faune of differents latitudes. Evolution. Vol. 11, Num. 3. pp: 298-299.

Lara-Juárez, P., J. R. Aguirre Rivera, P. Castillo Lara, y J. A. Reyes Agüero. 2015. Biología y aprovechamiento de la hormiga de escamoles, Liometopum apiculatum Mayr (Hymenoptera: Formicidae). Acta zoológica mexicana. Vol. 31, Núm. 2. pp: 251-264.

Lokeshwari, R. K., and T. Shantibala. 2010. A Review on the Fasci- 
nating World of Insect Resources: Reason for Thoughts. Psyche. Vol. 32, Num. 4. pp: 1-11.

Martella, Mónica B., Eduardo Trumper, Laura M. Bellis, Daniel Renison, Paola F. Giordano, Gisela Bazzano, y Raquel M. Gleiser. 2012. Manual de Ecología. Poblaciones: Introducción a las técnicas para el estudio de las poblaciones silvestres. Reduca (Ecología). Serie Ecología. Vol. 5, Núm. 1. pp: 1-31.

Martínez, Carmen Lidia, Maríz Begońa Riquelme-Virgala, Marina Vilma Santadino, Ana María de Haro, y Jutos José Barańao. 2015. Estudios sobre el comportamiento de Forrajeo de Acromyrmex lundi Guering (Hymenoptera, Formicidae) y su efecto sobre el crecimiento de procedencia de Eucalyptus globulus Labill (Mytaceae). Árvore. Vol. 39, Núm. 1. pp: 189-198.

Microsoft Office. 2013. Microsoft Excel 2013.

Miranda, A. Bruno, Kazuya Naoki, y Miguel Limanchi. 2012. Ensamble de hormigas en relación a cobertura vegetal en una zona periurbana de La Paz (Bolivia). Ecología en Bolivia. Vol. 47, Núm. 2. pp: 119-133.

Molinero, Luis Miguel. 2003. ¿Y si los datos no se ajustan a una distribución normal? Bondad de ajuste a una normal. Transformaciones. Pruebas no paramétricas. Asociación de la Sociedad Española de Hipertensión. Liga Española para la lucha contra la Hipertensión Arterial. Madrid, España.

Novoa, Sidney, Inés Redolfi, Aldo Ceroni, y Consuelo Arellano. 2005. El forrajeo de la hormiga Camponotus sp. en los botones florales del cactus Neoraimondia arequipensis subsp. roseiflora (Wendermann and Backenberg) Ostolaza (Cactaceae). Ecología aplicada, Vol. 4, Núm. 1,2. pp: 83-90.

Pirk, Gabriela I., Javier López De Casenave, y Rodrigo G. Pol. 2004. Asociación de hormigas granívoras Pogonomyrmex pronotalis, $P$. rastratus y $P$. inermis con caminos en el Monte central. Asociación Argentina de Ecología. Ecología Austral, Vol. 14, Núm. 1. pp: 65-76.

R: Copyright 2014. The $\mathrm{R}$ foundation for statistical computing Version 3.1.1

Ramos-Elorduy, J., Bernadette Délgade-Darchen, J. I. Cuadrillero Aguilar, N. Galindo Miranda, y José Manuel Pino Moreno. 1984. Ciclo de vida y fundación de las sociedades de Liometopum apiculatum M. (Himenoptera-Formicidae). Anales del Instituto de Biología UNAM serie Zoología. Vol. 55. pp: 161-176

Ramos-Elorduy, Julieta, Bernadette Darchen, Alberto Flores-Robles, Eusebia Sandoval-Castro, Socorro Cuevas-Correa. 1986. Estructura del nido de Liometopum occidentale var. luctuosum manejo y cuidado de estos en los nucleos rurales de México de las especies productoras de escamol (L. apiculatum M y L. occidentale var. luctuosum W.) (Hymenoptera-Formicidae). Anales Instituto de Biología Universidad Nacional Autónoma de México. Vol. 57, Serie Zoológica, Núm. 2. pp: 333-342.

Ramos-Elorduy, Julieta, Bernadette Délgade-Darchen y N. E. Galindo. 1988. Observaciones biotecnológicas de Liometopum apiculatum M. y Liometopum occidentale Var. Luctuosum W. (Himenoptera-Formicidae). Anales del Instituto de Biología UNAM serie Zoología. Vol. 59. pp: 341-354.

Ramos-Elorduy, Julieta. 1991. Los insectos como fuente de proteínas del futuro. Distrito Federal, México. Edit. Limusa S. A. primera reimpresión. p. 92.

Ramos-Elorduy, Julieta. 2005. Insectos comestibles de México. Distrito Federal, México. McGraw-Hill. 110 p.
Ramos-Elorduy, Julieta; José Manuel Pino Moreno, y Socorro Cuevas-Correa. 1998. Insectos comestibles de México y determinación de su valor nutritivo. Anales Instituto de Biología Universidad Nacional Autónoma de México, Ser. Zoológica. Vol. 69. pp: 65-104.

Ramos-Elorduy, Julieta, y José Manuel Pino Moreno. 2005. El consumo de insectos; una alternativa alimenticia sana y nutritiva. Día V. pp: 46-49.

Ramos-Elorduy, Julieta, José Manuel Pino Moreno, y Mariangela Conconi. 2006. Ausencia de una regulación y normalización de la explotación y comercialización de insectos comestibles en México. Folia Entomológica Mexicana. Vol. 45, Núm. 3. pp: 291-318.

Ramos-Elorduy, Julieta. 2008. Energy supplied by edible insects from Mexico and their nutritional and ecological importance. Ecology of food and nutrition. Vol. 47, Núm. 3. pp: 280-297.

Ramos-Elorduy, Julieta, José Manuel Pino Moreno, y V. H. Martínez. 2008. Una visita a la biodiversidad de la antropoentomofagia mundial. In: E. G. Estrada-Venegas, A. Equihua-Martínez, J. R. Padilla-Ramírez, y A. Mendoza-Estrada (eds). 2008. Entomología Mexicana. Sociedad Mexicana de Entomología y Colegio de Postgraduados. Montecillo, Texcoco, Estado de México, México. Vol. 7. 1092 p.

Rzedowsky, J. 1978. Vegetación de México: Ciudad de México. México: Limusa Wiley.

Rzedowski, J., y L. Huerta. 1994. vegetación de México (No. QK211. R93 1978.). México: Limusa, Noriega Editores.

Ruiz-Cancino, Enrique, Dimitri R. Kasparyan, Juana María Coronado-Blanco, Svetlana N. Myartseva, Vladimir A. Trjapitzin, Sonia G. Hernández-Aguila, y Jesús García-Jímenez. 2010. Hymenopteros de la Reserva El Cielo, Tamaulipas, México. Universidad de Guadalajara. Dugesiana. Vol. 17, Núm. 1. pp: 53-71.

Rojas-Fernández, P. 2001. Las hormigas del suelo en México: Diversidad, distribución e importancia (Hymenoptera: Formicidae). Acta Zoológica Mexicana (nueva serie). Es. 1. pp: 189-238.

Stradling, D. J. 1978. Food and feeding hábitats of ants. International Biological Programme.

Tarango-Arámbula, Luis Antonio. 2012. Los escamoles y su producción en el Altiplano Potosino-Zacatecano. X Simposium-Taller Nacional y III Internacional Producción y Aprovechamiento del Nopal y Maguey. RESPYN: Revista Salud Pública y Nutrición, Edición Especial, Vol.4. pp: 139-144.

Tizon, Francisco Rodrigo, Daniel V. Peláez, y Omar E. Elía. 2010. Efecto cortafuegos sobre el ensamblaje de hormigas (Hymenoptera, Formicidae) en una región semiárida, Argentina. Iheringia, Ser. Zoológica, Porto Alegre. Vol. 100, Núm. 3. pp: 216-221.

Velasco-Corona, Cecilia, María del Carmen Corona-Vargas, y Rebeca Peña-Martínez. 2007. Liometopum apiculatum (Formicidae: Dolichoderinae) y su relación trofobiótica con Heminoptera esternorrhyncha en Tlaxco, Tlaxcala, México. Acta Zoológica Mexicana (Nueva serie). Vol. 23, Núm. 2. pp: 31-42.

Villegas, D., A. Daza, B. Kohlmann, y J. Tejada. 2005. Estudio de prefactibilidad para la reproducción y comercialización de escarabajos del género Phaenaeus MacLeay. Tierra Tropical. Vol. 1, Núm, 1. pp: 61-67. 